\title{
Application of Different Separation Methods to Investigate the Baseflow Characteristics of a Semi-Arid Sandy Area, Northwestern China
}

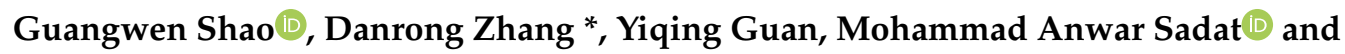 \\ Feng Huang ${ }^{D}$ \\ College of Hydrology and Water Resources, Hohai University, Nanjing 210098, China; \\ guangwenshao@hhu.edu.cn (G.S.); yiqingguan@hhu.edu.cn (Y.G.); m2017097@hhu.edu.cn (M.A.S.); \\ huangfeng1987@hhu.edu.cn (F.H.) \\ * Correspondence: danrong_zhang@hhu.edu.cn; Tel.: +86-177-6172-4730
}

Received: 4 January 2020; Accepted: 30 January 2020; Published: 6 February 2020

check for updates

\begin{abstract}
The Hailiutu River basin is a typical area of semi-arid sandy land with relatively flat topography, the surface of which is covered by undulating dunes and the development of the river system is not obvious. The dominant hydrological cycle is precipitation infiltration through dunes to aquifers followed by discharge to rivers. Therefore, the baseflow is an important component of the streamflow in this basin, but few studies for the baseflow characteristics have been conducted. The isotope tracer technique was applied to investigate the contributions of groundwater, soil water, and surface water to streamflow during the flood period. The results showed that the contributions of these components to streamflow were approximately $70 \%, 27 \%$, and $3 \%$ respectively. Several automatic baseflow separation methods including filtering and recursive digital filtering (RDF) techniques were adopted to separate the baseflow from the streamflow and the adaptabilities of these methods were evaluated. All the filtering methods including Hydrograph Separation Program (HYSEP) and UK Institute of Hydrology's method (UKIH) clearly underestimated the baseflow when compared with the standard baseflow results which were provided by the previous study using the tracer-based method in this basin, while the recursive digital filtering with Eckhardt filter technique (RDF-E) produced better performance. In the nonprecipitation period, the RDF-E method misidentified quick flow values which caused deviations between the separated baseflow and the above standard value. Hence, we proposed a modified automatic baseflow separation method called RDF-M by introducing the precipitation information into RDF-E. In comparison with the above standard, the RDF-M method provided similar baseflow results which were consistent with the actual situation of the Hailiutu River basin.
\end{abstract}

Keywords: baseflow; separation method; water components; semi-arid sandy area

\section{Introduction}

There are different components of streamflow during a precipitation process, such as surface flow, interflow, baseflow, and so on. Commonly, the streamflow can be divided into two components which are quick flow and baseflow. The quick flow, such as surface flow or interflow, responds quickly to rainfall events, while baseflow whose main source is groundwater presents a slow response to rainfall events $[1,2]$. Baseflow plays a critical role in maintaining water ecological health and water quality. Investigation for baseflow can assist in the estimation of groundwater recharge, groundwater storage variation, and water management [3-6]. It also can be applied to explore the hydrological processes of catchment or improve the accuracy of streamflow prediction [7]. 
Currently, abundant methods for baseflow separation are available, of them, the graphical method, hydrological simulation method, tracer-based method, conductivity mass-balance (CMB) method, and automatic method are commonly used [8] (Table 1). The graphical method is easy to implement as it is based on empirical assumptions and user experiences [9]. However, this method is time consuming and arbitrary [10]. The hydrological simulation method applies mathematical equations to simulate the baseflow/quick flow to implement the baseflow separation process [11,12]. However, the hydrological model frequently needs numerous basic hydro-meteorological data and needs a large amount of time to calibrate the model parameters. The tracer-based method is considered as the most objective approach since it uses experimental data to achieve baseflow separation. This method is restricted to several rainfall events as it is laborious and expensive. Therefore, it is difficult to apply this method to separate the long time series of streamflow $[2,13]$. Considering the difficulty of obtaining water samples, researchers attempted to separate baseflow from streamflow with an alternative approach which relied on components of water itself. One of the most popular methods is the conductivity mass-balance $(\mathrm{CMB})$ technique, which is performed based on the differences in physical processes between baseflow and surface flow [14-16]. This method is also considered to be objective as it is based on basin-specific physical processes. However, how to reasonably obtain conductive values of surface flow and baseflow is still problematic since only conductive values of streamflow are available [15]. The automatic method, relying on filtering or the signal analysis approach, imitates manual separation behavior to achieve baseflow/quick flow separation and can quickly obtain baseflow using a computer program. Thus, it overcomes the subjectivity of the graphical method. This approach is widely applied to the study of baseflow separation although it lacks rigorous physical meaning.

Table 1. Introduction to the commonly used baseflow separation methods.

\begin{tabular}{ccc}
\hline Methods & Input Data & Example/Author \\
\hline Graphical & Streamflow and experience & Szilagyi and Parlange [9] \\
Hydrological simulation & Hydro-meteorological data & Arnold et al. [11] \\
Tracer-based & Streamflow and tracer values & Klaus et al. [13] \\
Conductivity mass-balance & Streamflow and specific conductive & Stewart et al. [16] \\
Automatic & Streamflow & Gustard et al. [17], Eckhardt [18] \\
\hline
\end{tabular}

Generally, the automatic method can be divided into the filtering method and the recursive digital filter (RDF) method [19]. Hydrograph Separation Program (HYSEP), Partitioning Computer Program (PART), and UK Institute of Hydrology's method (UKIH) belong to the filtering method, which is widely applied to various research $[17,19,20]$. The RDF method was proposed by Lyne and Hollick [21] and applied to separate the streamflow into quick flow and baseflow. In this method, the streamflow series was processed as the digital signal. It adopts a digital filter to separate the streamflow series into baseflow and quick flow when quick flow corresponds to high-frequency signals and baseflow to low-frequency signals. In recent years, numerous digital filters have been proposed to implement RDF $[18,22]$. Among them, the Eckhardt filter (RDF-E) is a utility filter, as it has two parameters to reflect the groundwater recession and geological characteristics $[18,23]$. These two parameters are the recession constant $\alpha_{g w}$ and the maximum value of baseflow index (the ratio of baseflow to the total streamflow) $\left(B F I_{\max }\right.$ ) but the value of baseflow constitutes $B F I_{\max }$ cannot be obtained directly while the former can be estimated from recession analysis [18]. RDF method may mistakenly identify the sharp changes of streamflow as quick flow since irrigation water withdrawals may as well cause these variations [2]. Therefore, by integrating the precipitation data into the RDF method, more reliable baseflow/quick flow results can be obtained.

Numerous researchers studied the baseflow processes in different regions, such as low land [19], mountain [24], glacier melt dominated area [23], karst catchments [25], loess plateau [26], and so on. However, little attention has been paid to the semi-arid sandy land. The Hailiutu River basin is a typical semi-arid sandy area rich in mineral resources such as natural gas, coal, and oil. In recent years, with economic development, water scarcity is acute, and the contradiction between 
water resources development and utilization with ecological protection is becoming prominent. This basin allows researchers to study the water cycle and ecosystem for understanding the hydrological and aquatic ecological characteristics of the semi-arid sandy area [27-29]. Meanwhile, researchers adopted statistical analysis, hydrological modeling, or experimental method to study the variation characteristics of runoff [30-33]. In this area, the surface is mainly covered by undulating dunes, the topography is relativity flat, and the dominant hydrological cycle is precipitation infiltration through dune to aquifers followed by discharge to rivers; therefore, the baseflow is an important component of the streamflow [34]. Yang et al. found that the baseflow index was around $96.4 \%$ during one year and this value is also up to $75 \%$ during flood events by the tracer-based method [35]. However, there are still some questions about the baseflow that should be further analyzed. Such as: what is the contribution of soil water to the streamflow during a flood event and which baseflow separation method is more suitable in the semi-arid sandy area?

The objectives of this paper are: (1) to investigate the contributions of groundwater, soil water, and surface water to the streamflow during the flood event; (2) to compare the performance of different baseflow separation methods and propose a new baseflow separation method by introducing precipitation data; (3) to analyze the baseflow/quick flow characteristics under long time scale. The results obtained in this study can provide guidance for water resources management and planning in the local government.

\section{Materials and Methods}

\subsection{Study Area}

The Hailiutu River is a branch of the Wuding River of the Yellow River basin and belongs to the Erdos Plateau in northwest China. The Hailiutu River basin is located between $38^{\circ} 02^{\prime}$ to $38^{\circ} 50^{\prime} \mathrm{N}$, and $108^{\circ} 37^{\prime}$ to $109^{\circ} 14^{\prime} \mathrm{E}$, covering an area of $2500 \mathrm{~km}^{2}$ (Figure 1). The elevation of the Hailiutu River basin ranges from $1471 \mathrm{~m}$ in the northwest region to $1016 \mathrm{~m}$ at the watershed outlet. It has a relatively flat topography and the land surface is mainly characterized by undulating dunes and low hills at the northern and western water divide. Only about $5 \%$ of areas of this basin have a surface slope greater than $5^{\circ}$ which is mainly located in the valley bottoms [34]. This basin is a part of Mu Us desert, but around $88 \%$ surface area of which is covered by xeric shrubland [33]. The geological formation in the Hailiutu River basin can be divided into four strata: (1) the Holocene Aeolian sand with a thickness of 0 to $50 \mathrm{~m}$; (2) the upper Pleistocene Shalawusu sandstone formation of the Quaternary age with a thickness of 5 to $90 \mathrm{~m}$; (3) the Luohe sandstone of Cretaceous age with a thickness of 180 to $330 \mathrm{~m}$, overlain with the Shalawusu formation; and (4) the bedrock, which consists of impermeable Jurassic sediments [30]. The study area is under a semi-arid climate with unevenly distributed precipitation. Mean annual precipitation is $330 \mathrm{~mm}$ of which about $80 \%$ annual rainfall occurs during the rainy season (June to September). The Hailiutu River has a relatively steady discharge even in the dry season (October to May) as groundwater is the primary source of streamflow [36].

\subsection{Data}

The observed historical daily rainfall and streamflow data of the Hailiutu River basin (1957-2014) were used in this study provided by the Yellow River Conservancy Commission. Some statistical indexes of average streamflow and precipitation which were calculated at an annual scale were listed in Table 2. It was found that the standard deviation of streamflow was smaller than its average, resulting in a small value of the coefficient of variation. That means the inter-annual variation of streamflow was uneven. Similarly, the inter-annual variation of precipitation was also uneven but its variation was weaker than that of streamflow. 
Table 2. Statistical values of Hailiutu River Basin for annual average streamflow and precipitation.

\begin{tabular}{cccccc}
\hline Items & Minimum & Maximum & Mean & Standard Deviation & Coefficient of Variation \\
\hline Streamflow $\left(\mathrm{m}^{3} / \mathrm{s}\right)$ & 1.3 & 5.03 & 2.62 & 0.61 & 0.23 \\
Precipitation $(\mathrm{mm})$ & 143.5 & 748.8 & 358.2 & 110.4 & 0.31 \\
\hline
\end{tabular}

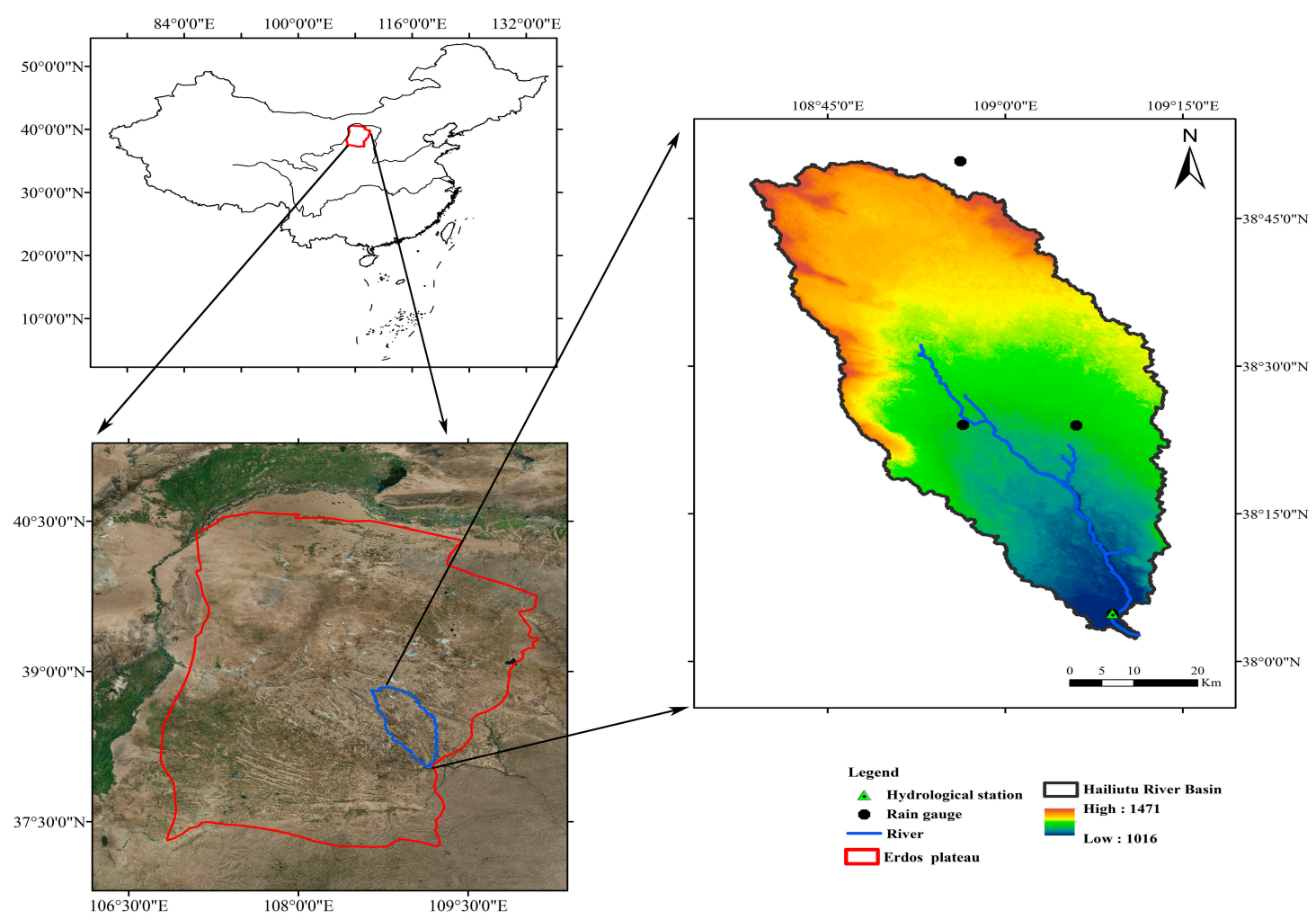

Figure 1. Summary of the study area: location of the catchment, observation stations, and digital elevation model.

To analyze the contributions of surface water, soil water, and groundwater to streamflow during the flood period, field experiment was carried out from 23 July to 31 July 2016 in the riparian zone. During the experiment, water samples of rainfall water, soil water, groundwater, and stream water were collected to analyze stable water isotopes oxygen-18 $\left({ }^{18} \mathrm{O}\right)$ and deuterium $\left({ }^{2} \mathrm{H}\right)$. A rain bucket was used to collect rainfall water. The "Rhizon" soil moisture sampler was used to collect soil water and it can extract a 5-10 mL volume of interstitial soil pore water without significantly disturbing the structure [37]. Groundwater was collected through a well with a depth of about $2 \mathrm{~m}$. Stream water was directly collected from the stream. Meanwhile, precipitation was measured using an automatic tipping-bucked rain gauge (model name: Onset HOBO RG3-M, diameter: $15.24 \mathrm{~cm}$, and resolution: $0.2 \mathrm{~mm}$ ). $\mathrm{ECH}_{2} \mathrm{O} 5 \mathrm{TE}$ sensors of Decagon Devices, Pullman, Washington, USA were applied to measure soil water content and Decagon's EM50 data logger was adopted to record the output signal from the 5TE sensors (30 min resolution).

\subsection{Methods}

In this paper, tracer-based and automatic separation methods were used to separate the baseflow from streamflow and the automatic method includes filtering and recursive digital filtering (RDF) separation methods. For the filtering method, HYSEP and UKIH were adopted to implement the separation. The RDF with Eckhardt filter called RDF-E and modified RDF-E by introducing precipitation information called RDF-M were used to perform the separation. 


\subsubsection{Tracer-Based Method}

In this study, isotopes were used as the tracer to implement the tracer-based method. Commonly, with $\mathrm{n}$ isotopic signatures, the contributions of $\mathrm{n}+1$ water sources to the streamflow can be determined [38]. A typical equation [38] using two isotopic signatures $\left(\delta^{1}\right.$ and $\left.\delta^{2}\right)$ to separate the contributions $(C)$ of three water sources to the streamflow $(r)$ is

$$
\left\{\begin{array}{l}
\sum_{i=1}^{3} C_{i} \delta_{i}^{1}=\delta_{r}^{1} \\
\sum_{i=1}^{3} C_{i} \delta_{i}^{2}=\delta_{r}^{2} \\
\sum_{i=1}^{3} C_{i}=1
\end{array}\right.
$$

When only one isotopic signature was applied to identify the contribution of two water sources to streamflow, Equation (1) can be rewritten as follows:

$$
\left\{\begin{array}{l}
\sum_{i=1}^{2} C_{i} \delta_{i}^{1}=\delta_{r}^{1} \\
\sum_{i=1}^{2} C_{i}=1
\end{array}\right.
$$

It is noted that several assumptions as follows should be satisfied when using the above equations to investigate the contributions of different components to the streamflow.

(1) The isotope values of all investigated components are significantly different;

(2) The isotope signatures of all investigated components are constant in space and time, or the variations of them can be accounted for;

(3) The contributions of surface storage to streamflow can be ignored $[13,19]$.

\subsubsection{Automatic Methods}

\section{UK Institute of Hydrology's Method (UKIH)}

The UKIH method was proposed by the Institute of Hydrology and programed by Gustard et al. [17] and according to Koskelo et al. [2], the detailed procedures of UKIH can be arranged as follows:

Step 1: Mean daily streamflow was divided into $\mathrm{n}$ nonoverlapping blocks of $\mathrm{N}$ days to calculate the minimum daily streamflow $q_{i}$ of each block $i$ for the day $d_{i}$ and was recorded as $q_{1}, q_{2} \ldots, q_{n}$ for the corresponding day $d_{1}, d_{2}, \ldots, d_{n}$.

Step 2: For each minimum streamflow $q_{i}$, the following equation was tested. If $q_{i}$ satisfied Equation (3), then the baseflow is $q_{i}$.

$$
q_{i-1} \leq 0.9 \cdot q_{i} \leq q_{i+1}
$$

Step 3: By linear interpolation, daily baseflow $q_{b}$ between each successive baseflow day $d_{i}$ was computed.

Step 4: For any given day, if the computed baseflow $q_{b}(i)>$ total streamflow $Q_{i}$ then the computed baseflow $q_{b}(i)=$ total streamflow $Q_{i}$.

In the original $\mathrm{UKIH}$, the $\mathrm{N}$ was specified as a fixed value ( 5 days), but it failed to reflect the varying hydrological conditions of the watershed with different sizes [39]. Therefore, the variation of baseflow index (BFI) with change in N should be noted when UKIH is applied in different watershed [40].

Hydrograph Separation Program (HYSEP)

The HYSEP method was proposed by Pettyjhon and Henning [41] and it was compiled as a program by White K E and Sloto R A [42]. HYSEP can be divided into fixed interval (H-Fixed), sliding-interval (H-Sliding), and local-minimum (H-LM) method. The procedures are as follows: 


\section{H-Fixed Method}

Step 1: Identify the duration of quick flow from the empirical Equation (4). The interval of calculation was approximately $2 \mathrm{~N}$ and adjusted to the nearest odd integer from 3 to 11 (i.e., if the value of $2 \mathrm{~N}$ is 4.2 then the adjusted value will be 5 and so on).

$$
N=0.84 A^{0.2}
$$

where $\mathrm{N}$ is the duration of quick flow (days); $\mathrm{A}$ is the watershed area $\left(\mathrm{km}^{2}\right)$.

Step 2: The minima of streamflow in each interval was calculated and the minimum value of that point was assigned to all days of the interval period. Then the interval block was shifted $2 \mathrm{~N}$ days horizontally along the hydrograph and the process was repeated. The assigned daily values of every interval blocks were connected to define the baseflow hydrograph.

\section{H-Sliding Method}

The interval block was made by $2 \mathrm{~N}-1$ days to calculate minimum discharge of each interval but this value was assigned to median days in that interval. Then, the block was slid to the next day and the process was repeated. Finally, the assigned daily values were connected to define the baseflow hydrograph.

\section{H-LM Method}

In this case, $2 \mathrm{~N}-1$ days interval block was made to check each day in the interval for determining the lowest discharge that satisfied the criteria of the local minima of the hydrograph. Then, the blocks were shifted the next day and the process was repeated. If the day satisfied the criteria then a straight line was drawn connected to the adjacent local minima which defined the baseflow hydrograph.

\section{Recursive Digital Filtering Method (RDF)}

In this paper, RDF-E, which was proposed by Eckhardt [18], was applied to drive the RDF method to separate baseflow by the following equation:

$$
q_{b}(i)=\frac{\left(1-B F I_{\max }\right) \alpha_{g w} q_{b}(i-1)+\left(1-\alpha_{g w}\right) B F I_{\max } Q(i)}{1-\alpha_{g w} B F I_{\max }}
$$

As mentioned above, from the above equation, RDF-E requires the determination of recession constant $\alpha_{g w}$ and maximum value of the baseflow index $\left(B F I_{\max }\right)$ and the recession analysis was used to estimate the value of recession constant $\alpha_{g w}$ [43]. According to the assumption of the linear reservoir, the groundwater outflow can be estimated by Equation (6) during the groundwater recession process. Ideally, in a plot of $Q(i)$ against $Q(i-1)$, all points should be on a straight line across the origin, and the slope of the line is the groundwater recession constant $\alpha_{g w}$.

$$
Q(i)=\alpha_{g w} Q(i-1)
$$

Eckhardt considered $B F I_{\max } 0.80$ for perennial streams with porous aquifers, 0.5 for ephemeral streams with porous aquifers, and 0.25 for perennial streams with hard rock aquifers [18]. However, Eckhardt suggested these values based on study results of several typical watersheds, and therefore, these may have some differences in actual situations in some other watersheds. Eckhardt also recommended other approaches, e.g., the tracer experiments to calibrate the $B F I_{\max }$ value. In this study, the $B F I_{\max }$ value was estimated by a backward filtering operation which was proposed by Collischonn and Fan [44]. The maximum baseflow of the previous day can be estimated by Equation (7) which is generated from Equation (6):

$$
Q_{b}(i-1)=Q_{b}(i) / \alpha_{g w}
$$


During the groundwater recession period, all the streamflow should come from groundwater, i.e., baseflow is equal to streamflow. Then, maximum baseflow can be estimated by repeating Equation (7) and the maximum baseflow of one day should be confined to the streamflow of that day.

\section{Modified Recursive Digital Filtering Method (RDF-M)}

In this paper, based on the RDF-E method, we proposed a new RDF method RDF-M by introducing the precipitation information to improve the accuracy of baseflow separation. The detailed calculation procedure was presented in Figure 2. Firstly, accumulated precipitation of $\mathrm{N}$ days was calculated, where $\mathrm{N}$ is a quick flow duration caused by precipitation and its value can be confirmed by the observed flood processes or experiment. If the accumulated precipitation is greater than $T H_{p}$, then the RDF-E method is used to calculate the baseflow, otherwise, the baseflow is specified as streamflow of that day. $T H_{p}$ is a threshold that indicates whether quick flow has occurred and is specified as $1 \mathrm{~mm}$ in this study according to the results of Yang et al. [45].

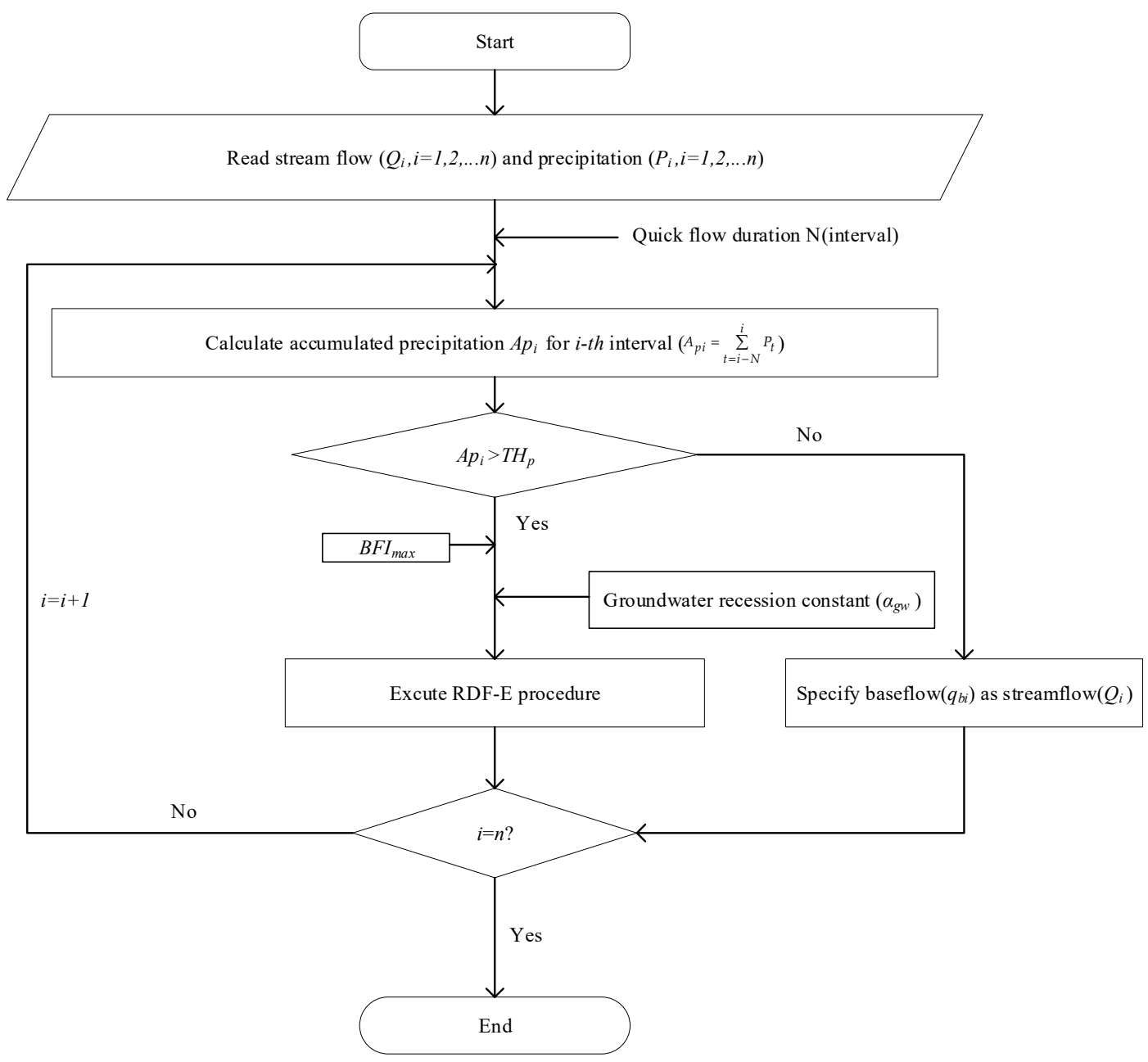

Figure 2. The flowchart of modified recursive digital filtering (RDF-M) method.

\section{Results}

\subsection{Tracer-Based Method}

During the experiment, only one precipitation event occurred (date: 24 July 2016, precipitation: $41.4 \mathrm{~mm})$. The temporal variations of water isotopes, oxygen-18 $\left({ }^{18} \mathrm{O}\right)$, and deuterium $\left({ }^{2} \mathrm{H}\right)$ were expressed as $\delta^{2} H$ and $\delta^{18} O$ respectively and these variations (unit: parts per thousand) with respect to precipitation, streamflow, groundwater, and soil water during the experiment are shown in Figure 3. 
The variation process of $\delta^{2} H$ and $\delta^{18} O$ was consistent although the values of the two were quite different. During the precipitation event, the isotope values of streamflow were composed of the isotope values of precipitation, soil water, and groundwater, indicating that the streamflow was recharged by these three water sources. For example, in the case of $\delta^{2} H$ at the time 24 July 2016, 13:00 h, the isotope values of the groundwater, soil water, and precipitation, streamflow were found $-75.4,-57.8,-100.7$, and -72.8 and in the case of $\delta^{18} O$, the isotope values of these components were found $-11.9,-7.5$, -10.6 , and -9.6 respectively (Figure 3). Now according to Equation (1), the contributions of these three components at that time were found to be $30.2 \%, 47.1 \%$, and $22.7 \%$ respectively, see Figure $4 \mathrm{a}-\mathrm{c}$. After the precipitation event, the isotope values of streamflow also made up the combined isotope values of soil water and groundwater in the same way we presented above, representing that the inflows of stream were from soil water and groundwater. Subsequently, the isotope values of streamflow and groundwater were found to be very close, which indicated that groundwater is the key source of streamflow.
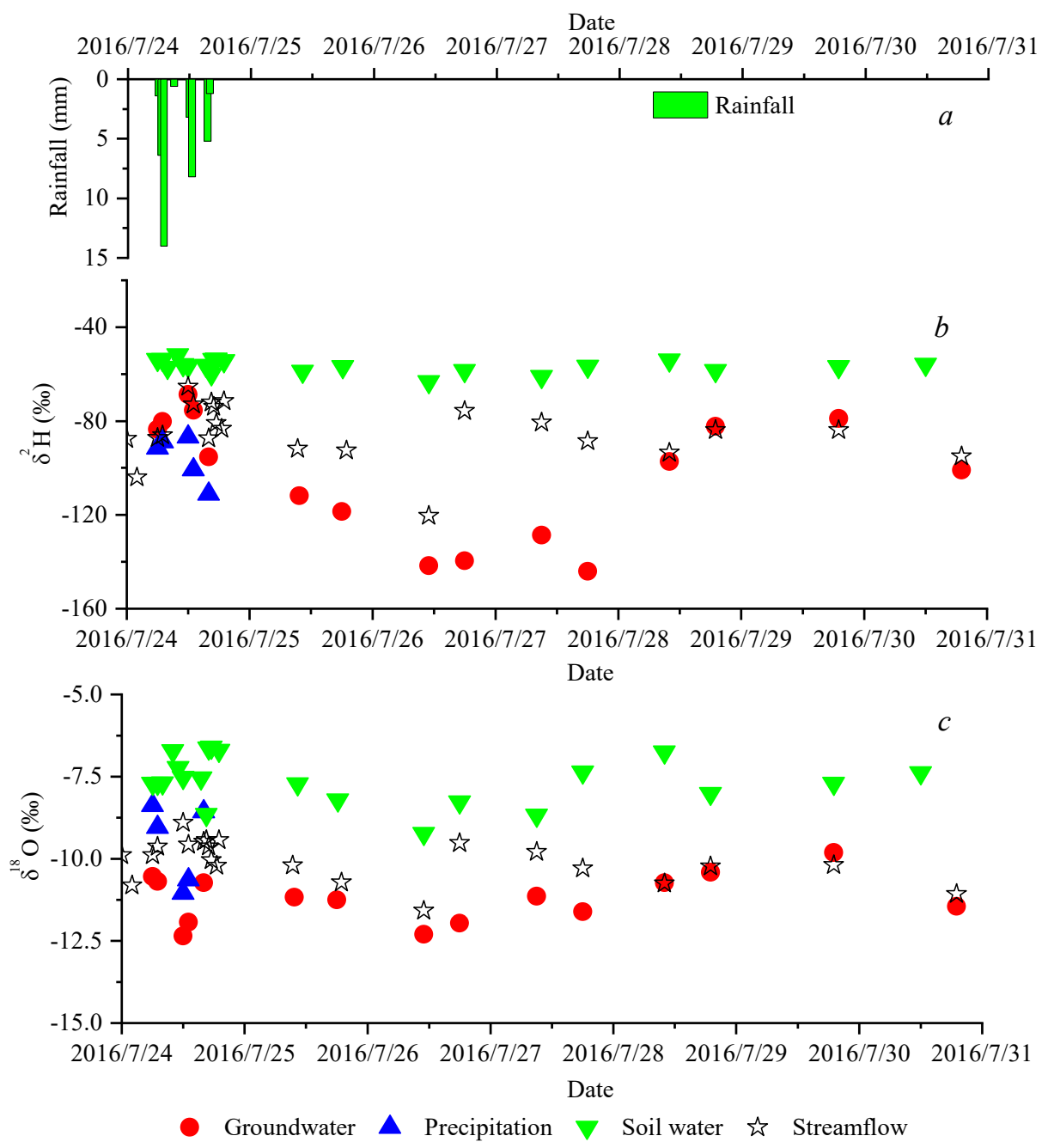

Figure 3. The variation of rainfall (a) and isotopic values $(\mathbf{b}, \mathbf{c})$ with respect to precipitation, stream water, groundwater, and soil water during the experiment. 

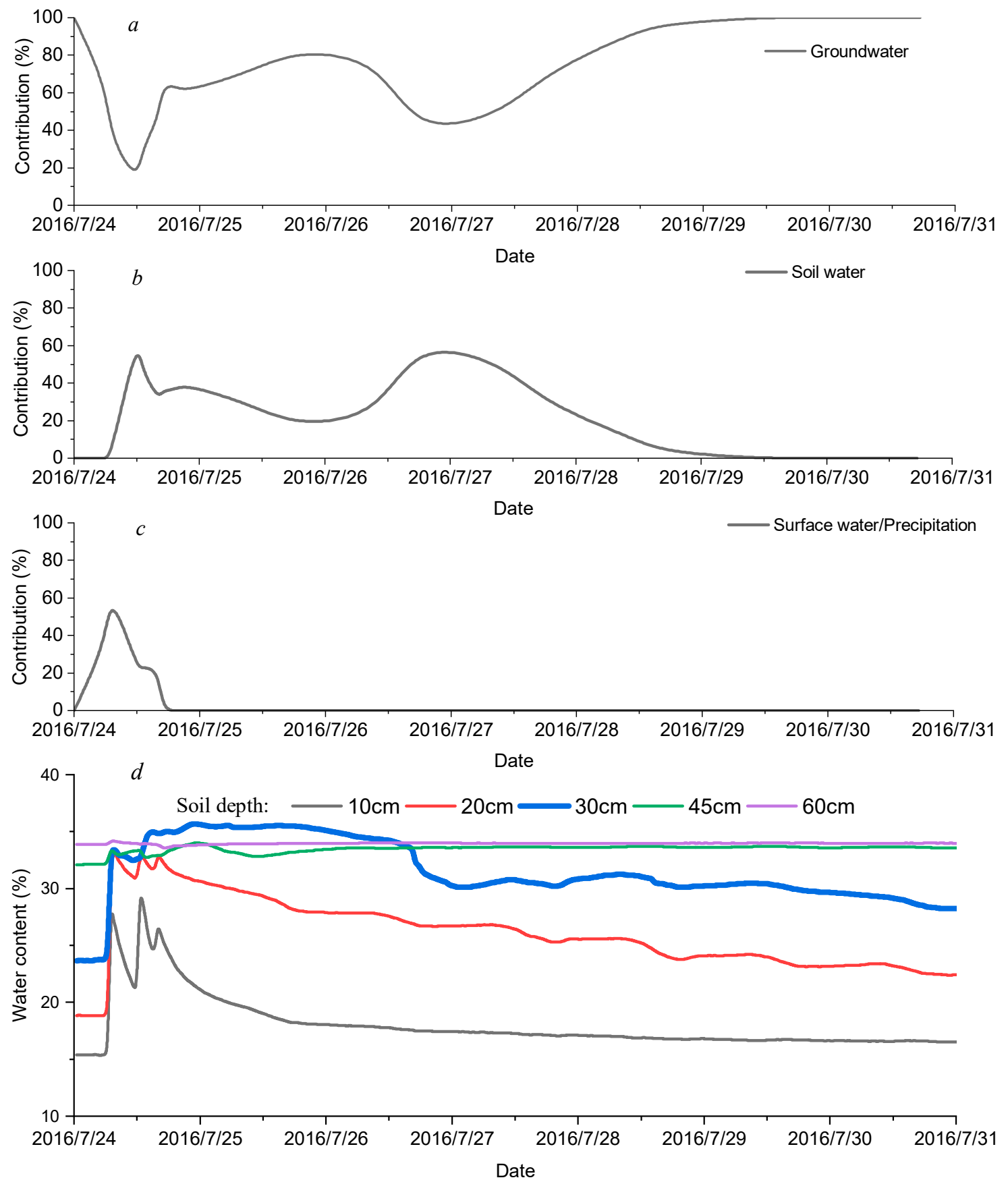

Figure 4. Percentage variations in the contribution of (a) groundwater, (b) soil water, and (c) surface water to streamflow and (d) percentage variation of water content in different soil depths during the experiment.

During the precipitation, the streamflow was composed of groundwater, soil water, and surface water while after the precipitation event only soil water and groundwater constituted the streamflow. Based on Equations (1) and (2), the contributions of different water sources to streamflow during the precipitation and after the precipitation event were analyzed (Figure 4). Meanwhile, the variations of water content in different soil depths measured during the experiment were also illustrated in Figure $4 \mathrm{~d}$. At the beginning of the precipitation event, the source of streamflow was mainly coming from groundwater. The soil water content increased quickly with the increase of precipitation and the role of groundwater to streamflow reduced accordingly. After the end of precipitation, during the period of about five days, the contribution of groundwater to streamflow showed an upward trend, and the 
contribution of soil water to streamflow showed a downward trend. The total contributions of these three water sources to the streamflow during the flood period can be estimated by the calculation of the area of the graph (Figure 4a-c) using the trapezoidal rule. If the area of graph (a), (b), and (c) is $A_{g}$, $A_{s}$, and $A_{s f}$ respectively, then the contribution of groundwater, soil water, and surface water to the streamflow will be in that order $\left(A_{g} /\left(A_{g}+A_{s}+A_{s f}\right)\right) \times 100 \%,\left(A_{s} /\left(A_{g}+A_{s}+A_{s f}\right)\right) \times 100 \%$, and $\left(A_{s f} /\left(A_{g}+\right.\right.$ $\left.\left.A_{s}+A_{s f}\right)\right) \times 100 \%$. Therefore, with this calculation, the estimated values of $A_{g}, A_{s}$, and $A_{s f}$ in percentage day were $3.65,1.43$, and 0.16 respectively and the contribution of groundwater, soil water, and surface water to streamflow were found to be about $70 \%, 27 \%$, and $3 \%$, respectively.

\subsection{The Results of Different Baseflow Separation Methods}

\subsubsection{Value of $\mathrm{N}$ for $\mathrm{UKIH}$}

To specify the value of $\mathrm{N}$ in the UKIH method, the frequency analysis of annual mean streamflow was done. The wet year, normal year, and dry year correspond to frequencies of $25 \%, 50 \%$, and $75 \%$. Then, $\mathrm{BFI}$ values with different $\mathrm{N}$ values under different hydrological conditions (rainy year, normal year, and dry year) were calculated based on the UKIH method. Results indicated that the BFI value presented a clear decreased tendency with increased $N$ until $N>6$ (Figure 5). Therefore, in this paper, the $\mathrm{N}$ of UKIH method was specified as 6.

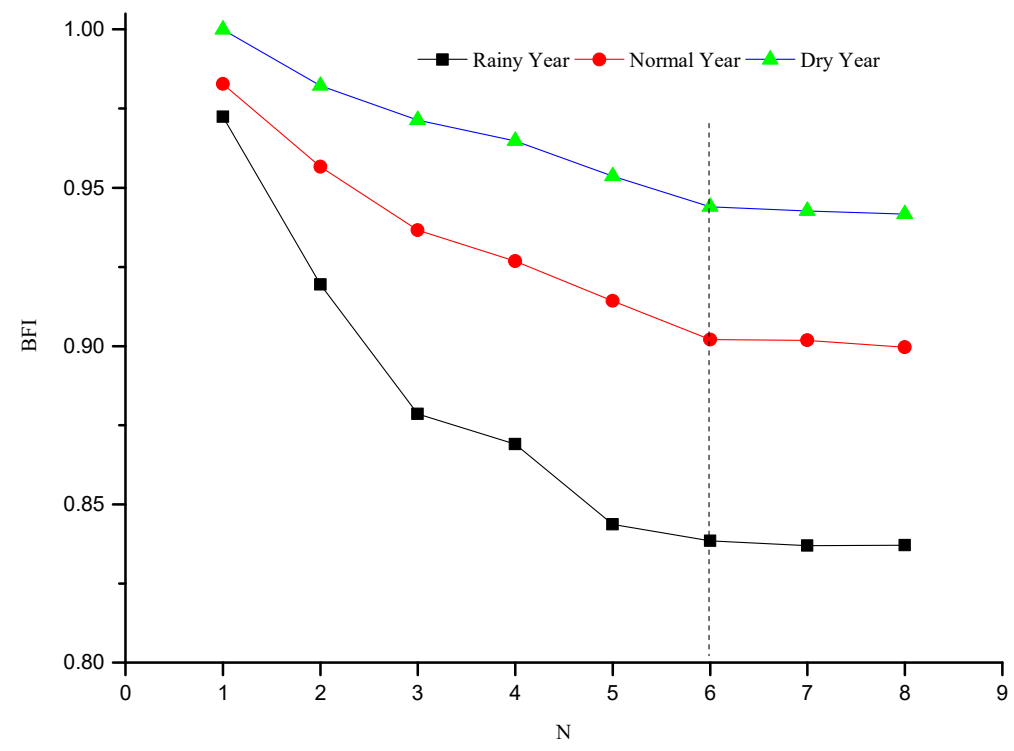

Figure 5. The baseflow index (BFI) value calculated by UK Institute of Hydrology's method (UKIH) with different $\mathrm{N}$ for a rainy year, normal year, and dry year, respectively.

\subsubsection{Value of Parameters for RDF-E}

In the RDF-E method, two parameters should be specified first. Using linear regression analysis, the groundwater recession constant $\alpha_{\mathrm{gw}}$ was estimated as 0.956 (Figure 6) and by the backwater filter proposed by Collischonn and Fan [44], the maximum baseflow index $B F I_{\max }$ was estimated as 0.92 .

\subsubsection{Value of $\mathrm{N}$ for RDF-M}

To determine the quick flow duration of the Hailiutu River basin, four typical flooding processes of this basin were selected, and the quick flow duration was found to be about five days (Figure 7). Therefore, in this study, the value of $\mathrm{N}$ for RDF-M was specified as five days. This value is also consistent with the value obtained from the tracer-based method (Section 3.1). 


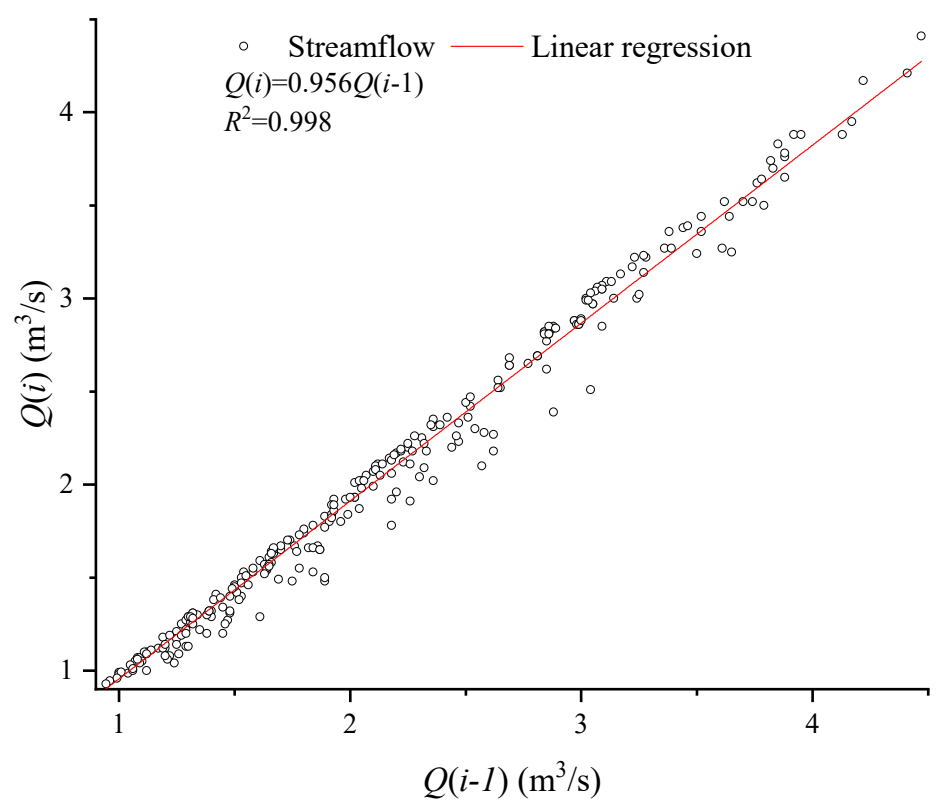

Figure 6. Scatter plot of streamflow $Q(i)$ against $Q(i-1)$ during recession period.

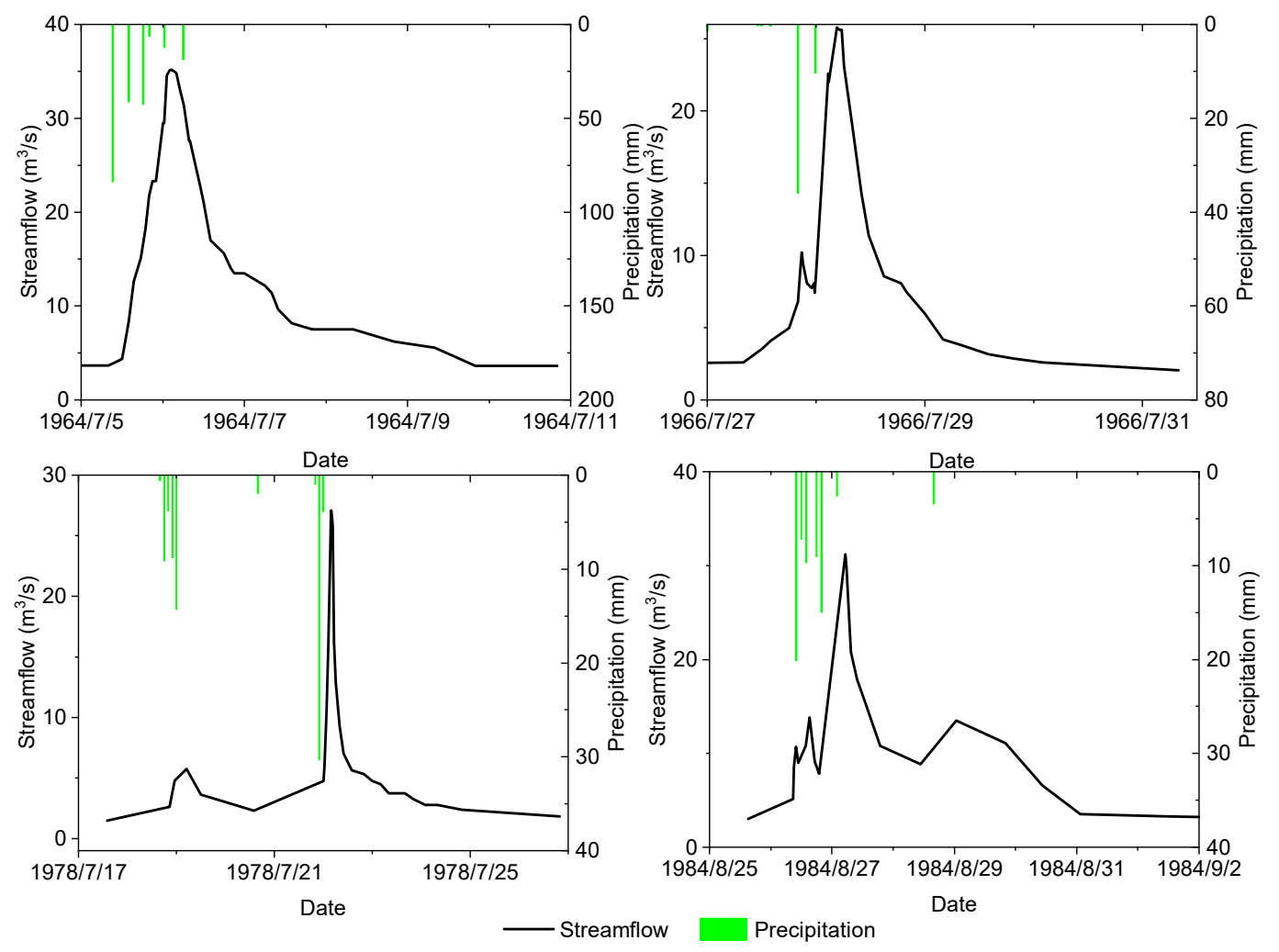

Figure 7. The streamflow process of typical flood events in the Hailiutu River basin.

\subsubsection{Performance of the Methods}

In this study, different automatic separation methods were applied to separate baseflow from streamflow (1 November 2010 to 31 October 2011) measured by Yang et al. [35]. For the HYSEP method, the interval blocks in the H-fixed method were specified as $10(2 \mathrm{~N})$ days, while in the H-sliding method and H-LM were specified as $9(2 \mathrm{~N}-1)$ days. Then, with these interval values, the baseflows by each method of HYSEP technique were determined. Using the UKIH method, the baseflow was separated from this observed streamflow data by the $\mathrm{N}$ values (six days) already determined in Figure 5. 
For the RDF-E method, the baseflow was separated from the same streamflow series considering the Equations (5)-(7) and Figure 6. In the case of the RDF-M method, the baseflow separation was performed following the flow chart as shown in Figure 2 by considering the quick flow duration of five days (Figure 7). Yang et al. [35] determined the baseflow using the tracer-based method which was an objective method to reflect the actual situation of the watershed of the study area (Figure 8h); thus, we took this result as a standard. Performances of the methods are shown below.

1. During the rainy season, the contribution of baseflow to streamflow was high (Figure 4). As shown in Figure 8 during the period 29 June 2011 to 6 July 2011, the separated baseflow of RDF-E and RDF-M nearly commensurated with the standard value, while other filtering methods failed to reflect this phenomenon. On the other hand, during the dry period (May to October) the streamflow was nearly equal to baseflow because inflows of the stream were mainly from groundwater at that time [30]. However, all the methods except RDF-M underestimated the baseflow during this period (Figure 8).

2. In Figure 9, the results of baseflow by using different automatic methods were compared to that of Yang et al. [35] by determining the Pearson correlation coefficient (R), and the comparisons between the individual methods were shown. The $\mathrm{R}$ values between each filtering method (HYSEP and UKIH) were found to be more than 0.9 which dictated that they produced similar baseflow results. Moreover, comparing with the standards, all the filtering methods significantly underestimated the baseflow and performed poorly (the highest $\mathrm{R}$ is only 0.587 ), while two RDF methods performed better than filtering methods $(R>0.9)$ and the RDF-M outperformed the RDF-E.

3. The performances of these methods were identified by the three quantitative statistics: (a) Nash-Sutcliffe efficiency (NSE), (b) Ratio of the root mean square error to the standard deviation of measured data (RSR), and (c) Percent bias (PBIAS). These statistics were selected because of their robustness in terms of applicability for various constituents, models, and climatic conditions and their versatility, acceptance, and recommendations in the published literature [46]. The large value of NSE indicates the high performance while the smaller the RSR value the better the performance will be and the small absolute value of PBIAS shows good performance. In reference to this, the HYSEP and UKIH methods performed poorly as NSE values were found to be small compared with RDF-E and RDF-M. Moreover, the recursive digital filtering methods outperform the filtering methods in terms of RSR and PBIAS (Table 3). In comparison to the RDF-E and RDF-M, the RDF-M performed better for the separation of baseflow from streamflow than the RDF-E according to the three statistics (Table 3).

4. Here, the performances of the different methods were determined based on baseflow distributions. In this case, we drew a histogram with the intervals of $0.005 \mathrm{~m}^{3} / \mathrm{s}$ (Figure 10). The results of the tracer-based method (standard) showed that the baseflow was mainly distributed in the interval of $0.03-0.045 \mathrm{~m}^{3} / \mathrm{s}$, and the peak appeared in the interval of $0.04-0.045 \mathrm{~m}^{3} / \mathrm{s}$ but the distributions determined by UKIH, HYSEP, and RDF-E were quite different than that of the tracer-based method, except RDF-M (Figure 10). The results of RDF-M were closer to the standard because of the inclusion of precipitation data.

5. Now, the performances of the different methods were compared based on baseflow index (BFI) obtained by using the historical streamflow data from 1957 to 2014. These baseflow indexes were divided into two groups, rainy season and dry season, and the differences between the two groups in terms of median value of BFI were considered. Commonly, during the rainy season, the increase in precipitation produced the increased quick flow as compared with the dry season. Therefore, the median value of BFI was different during the rainy season and dry season. As displayed in Figure 11, all methods including RDF-M followed this phenomenon except the RDF-E. This is because in the RDF-E method, the median value of BFI for the dry season and rainy season were found to be almost the same. 


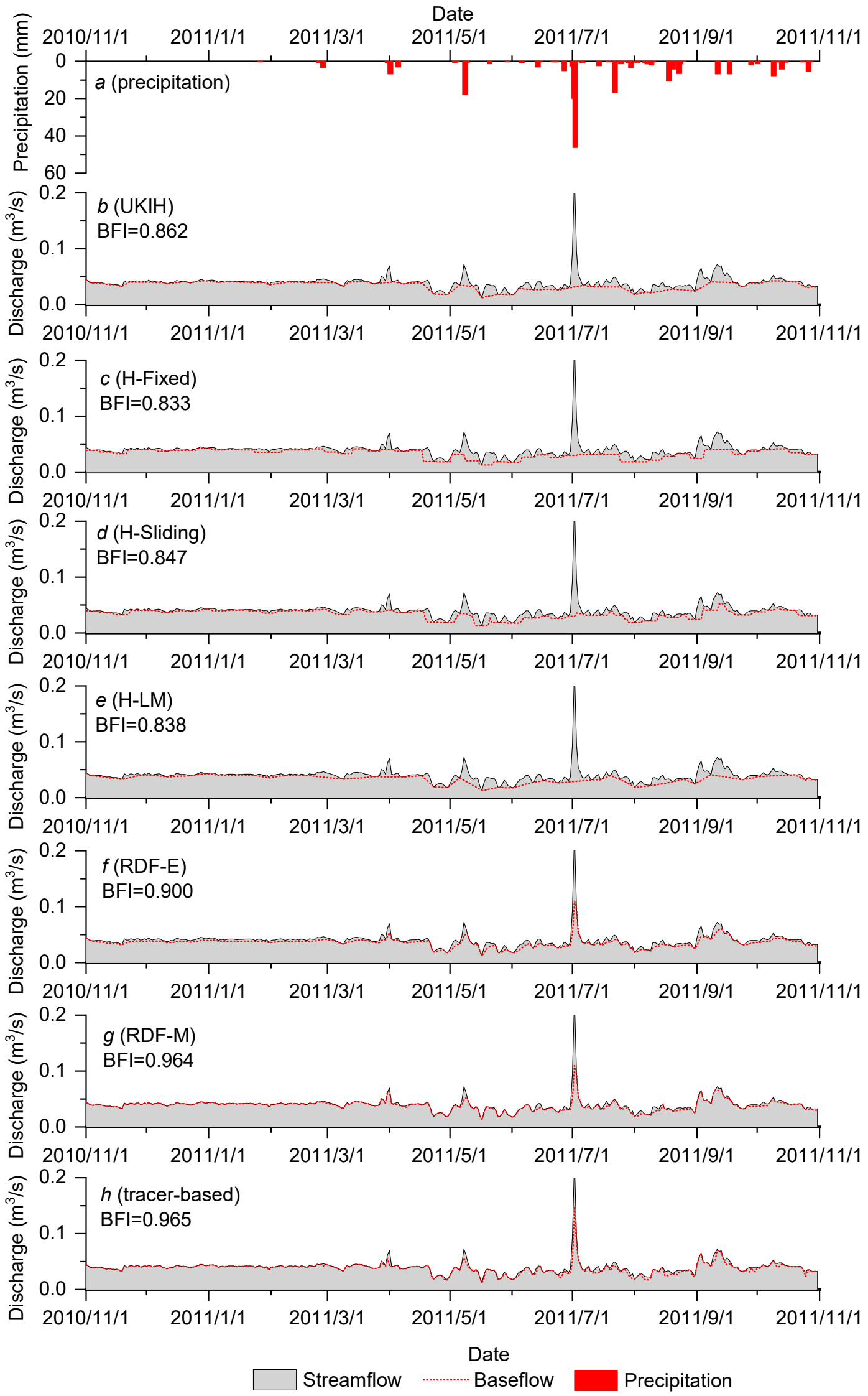

Figure 8. Scattered comparison of baseflow obtained by different baseflow separation methods. 


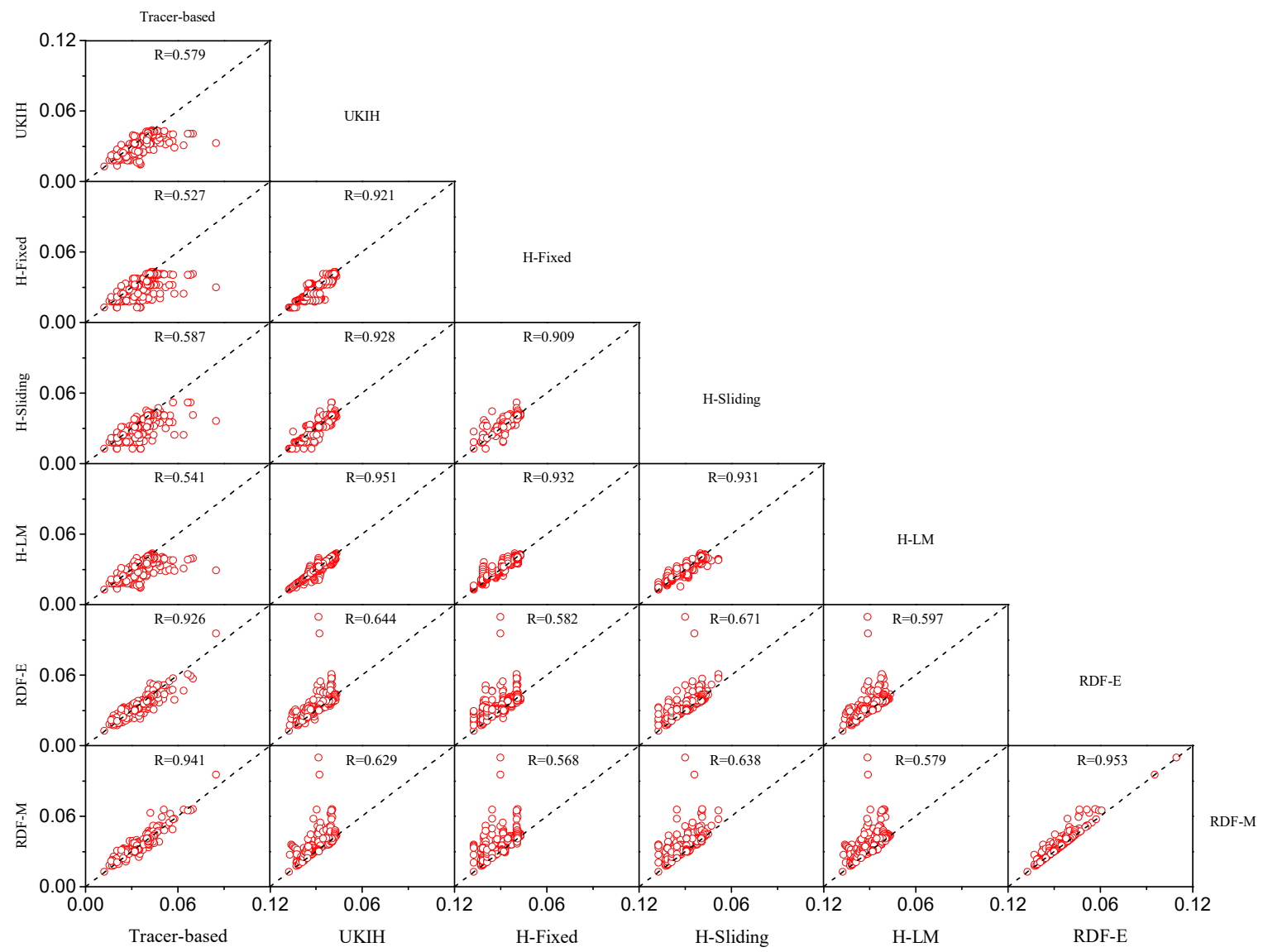

Figure 9. The distribution of daily BFI obtained by different automatic baseflow separation methods in the dry season and rainy season.

Table 3. The performance of different baseflow separation methods.

\begin{tabular}{cccc}
\hline Methods & NSE & RSR & RE \\
\hline UKIH & 0.23 & 0.88 & -8.18 \\
H-Fixed & 0.06 & 0.97 & -11.33 \\
H-Sliding & 0.18 & 0.9 & -9.73 \\
H-LM & 0.12 & 0.94 & -10.81 \\
RDF-E & 0.80 & 0.45 & -6.20 \\
RDF-M & 0.88 & 0.34 & 0.55 \\
\hline
\end{tabular}



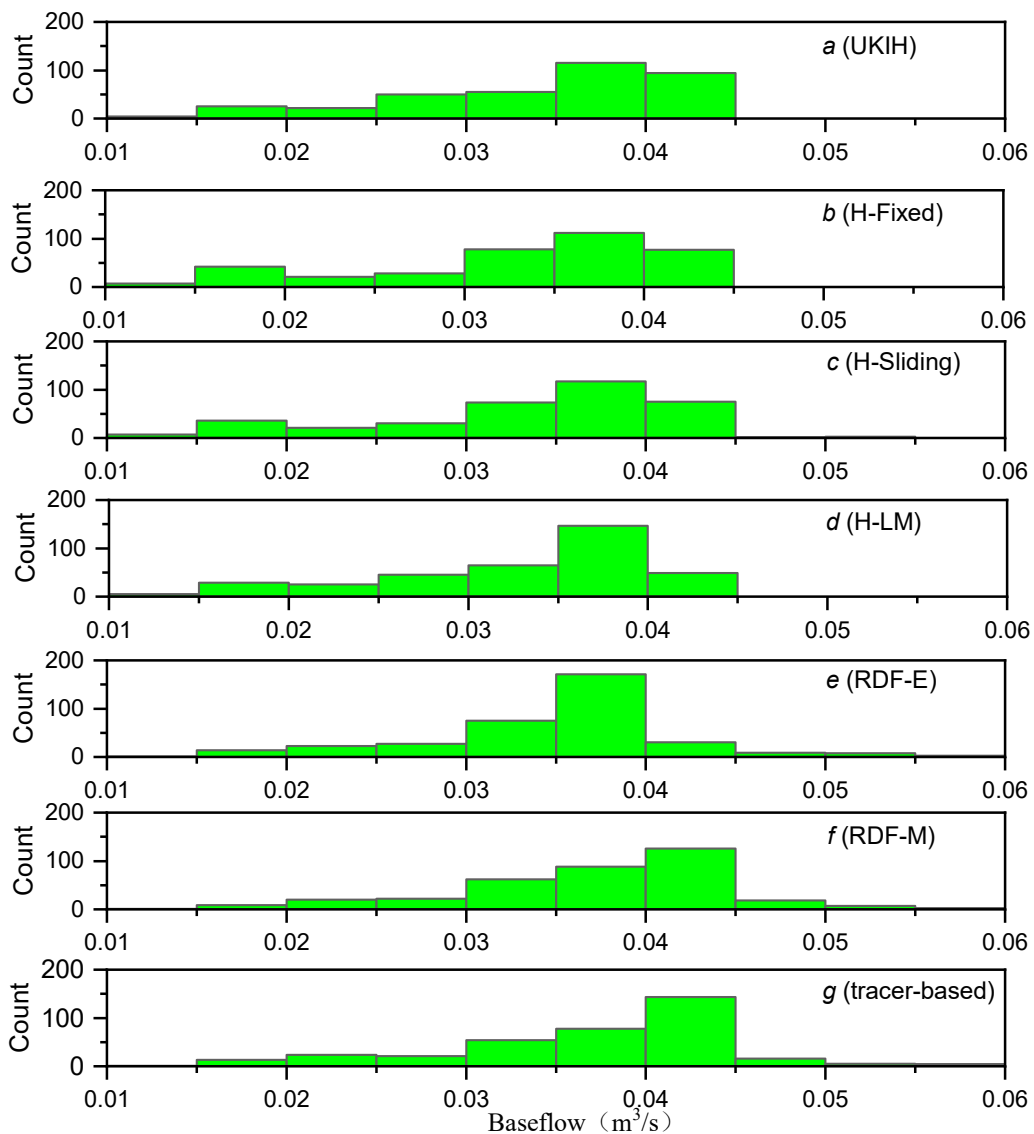

Figure 10. Histogram of baseflow obtained by different baseflow separation methods (a) UKIH, (b) H-Fixed, (c) H-Sliding, (d) H-LM, (e) RDF-E, (f) RDF-M, (g) tracer-based method.

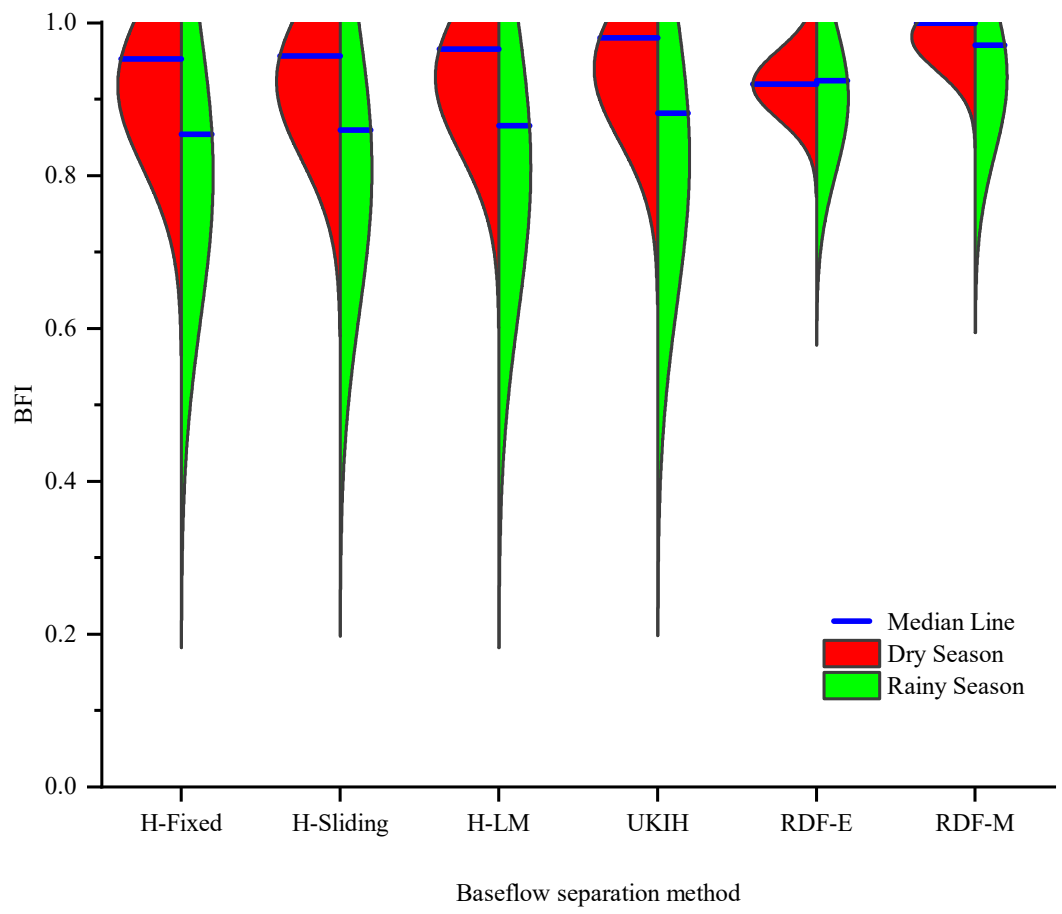

Figure 11. Comparison of baseflow variation process obtained by different baseflow separation methods (a) precipitation, (b) UKIH, (c) H-Fixed, (d) H-Sliding, (e) H-LM, (f) RDF-E, (g) RDF-M, (h) tracer-based method. 


\subsection{The Annual Variation of Mean Baseflow and Quick Flow by RDF-M Method}

The recursive digital filtering methods performed better than the other filtering processes with respect to different criteria presented in Section 3.2.4. It was shown that the RDF-M method outperformed the other methods. Therefore, the RDF-M method was applied to separate the baseflow and quick flow with the historical streamflow data between the period 1954 and 2014. The Mann-Kendall test (MK) [47] and the sequential t-test analysis of the regime shift (STARS) [48] were used to analyze the baseflow and quick flow trends and change points respectively. The MK test can be used for detecting trends in a time series without specifying whether the trend is linear or nonlinear and it is an excellent tool for trend detection, so many researchers have used this method to assess the significance of trends in hydroclimatic time series data such as water quality, streamflow, temperature, and precipitation [47]. The STARS method belongs to the category of exploratory or data-driven analysis that does not require a priori hypothesis on the timing of regime shifts. This greatly facilitates an application of the algorithm for automatic computations, when the number of variables processed can be practically unlimited. It also facilitates detecting a regime shift relatively early and then monitoring how its magnitude changes over time [48].

According to the MK test, the test statistic $Z$ values of baseflow and quick flow were found to be -6.25 and -3.11 respectively when analyzing the data on an annual scale. The test statistic's threshold value was 1.96 at the 0.05 confidence level [47]. Hence, the two flows possess a significant decreasing trend during the historical period (Figure 12). According to the STARS method, three change points $(1968,1986$, and 2001) were detected for annual baseflow and merely one point (1968) was detected for annual quick flow (Figure 12).
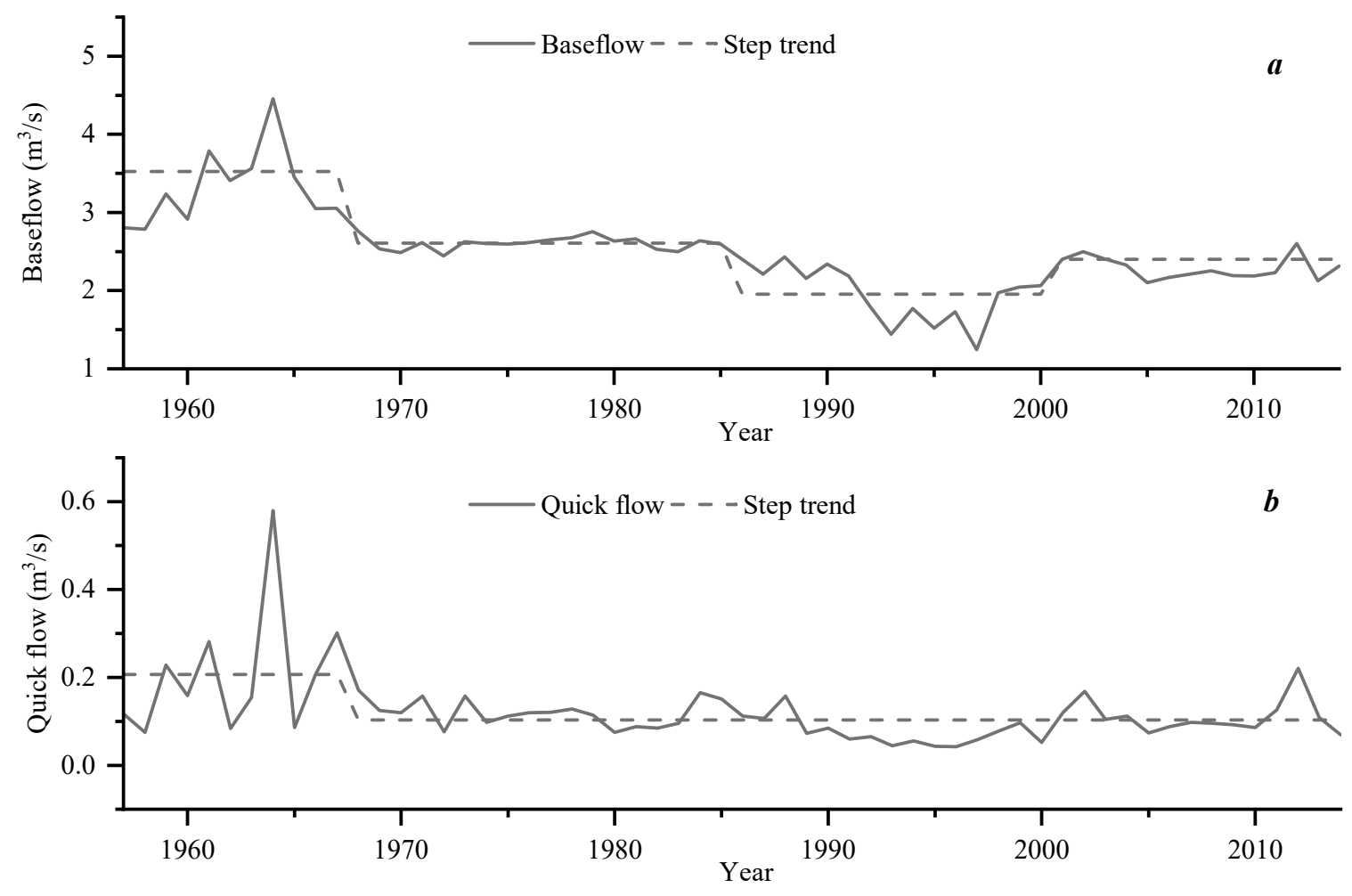

Figure 12. Flow regime shifts (a) annual mean baseflow and (b) annual mean quick flow.

\section{Discussion}

\subsection{The Contribution of Water Sources on Streamflow During the Flood Period}

In general, the tracer-based method is widely used for baseflow separation or runoff generation analysis since it is measurable, objective, and based on components of water itself [13]. In previous 
studies of our study area, only one tracer was used to partition the contributions of groundwater and rainfall water to streamflow neglecting the role of soil water [30,36]. However, during the experiment, we found that the significant difference of isotope values of groundwater and soil water and the isotope value of streamflow was composed of the isotope values of groundwater and soil water. Therefore, the isotope value of soil water was an important component of streamflow results (Section 3.1). In the experimental period, under the influence of heavy rainfall, the existence of surface runoff was observed in the riparian zone. After the precipitation, surface runoff was quickly converted to soil water due to the high infiltration rate of sandy soil. Therefore, in the paper, the contributions of surface water/precipitation, soil water, and groundwater to streamflow were considered during the rainfall event and only soil water and groundwater contributions were regarded after the rainfall event.

Generally, in the semi-arid area, during storm events, the surface flow is generated when the precipitation exceeds infiltration capacity. For sandy land, it seems the surface runoff has difficulty appearing as the final infiltration rates of sandy soil can exceed $100 \mathrm{~mm} / \mathrm{h}$ [49]. However, studies showed that precipitation intensity may exceed the infiltration rate of sandy land covered by biological topsoil crust as it may reduce the infiltration rate of soil significantly [50,51]. It was also shown that the surface runoff could be observed in a dune area covered by a biological crust [51]. In the riparian zone, soil moisture is higher than other areas, which helps the formation of biological crusts. During our experiments in the riparian zone, the high contribution of surface water to streamflow (up to $40 \%$ during the storm event in Figure 4) was observed and this phenomenon can be attributed to the riparian zone covered with biological crusts. The contribution of groundwater to streamflow decreased (minimum to $20 \%$ during the storm event in Figure 4) with the increased contribution of surface water and soil water. The variation of contributions of pre-event water obtained by Yang et al. [30] through two-component hydrograph separation also presented similar characteristics. It was noted that due to the high infiltration rate of the sandy land, surface runoff would disappear quickly after the heavy precipitation event. Therefore, during the flood period, the total contribution of surface water to streamflow is only 3\% (Section 3.1). In the experiment site, the groundwater level in the riparian zone was higher than the river water level, which indicated that groundwater continuously inflowed to the stream [30]. During the flood period, a small part of the precipitation in the form of surface runoff recharged the stream while most of the precipitation recharged soil water and groundwater due to the high infiltration rate of sandy land. Therefore, the contribution of groundwater to streamflow was also high even during a flood period.

\subsection{The Strengths and Weaknesses of the Different Automatic Methods}

In order to efficiently separate the base flow from streamflow, researchers have proposed many automatic baseflow separation methods; however, the performance of these methods varies significantly in different areas $[14,19]$. For the semi-arid sandy area, different methods need to be compared and analyzed, and a method suitable for the area should be selected. Therefore, in this study, isotope-based method was used to evaluate the performance of several common automatic baseflow separation methods. For the RDF-E method, we need to determine the values of $\alpha_{g w}$ and $B F I_{\max }$ where $\alpha_{g w}$ can be determined using the recession analysis (Figure 6). Generally, the value of $B F I_{\max }$ is dependent on the hydrological and hydrogeological characteristics of the area, which has a greater impact on the separation results than $\alpha_{g w}$ and can be calibrated by the isotope-based method [18]. RDF-E method with a larger $B F I_{\max }$ value can obtain a higher baseflow. Researchers also used the results of the conductivity mass balance (CMB) method or simulation results of the hydrological model to calibrate the parameter $B F I_{\max }[14,52]$. In this paper, we used the backward filtering operation method to determine the value of $B F I_{\max }$, which is entirely based on discharge records and found that the value was 0.92 (Section 3.2.2). This value exceeded the maximum value (0.80) suggested by Eckhardt (Section 2.3.2), which was supported by other research $[19,44]$. It was noted that the value of $B F I_{\max }$ is dependent on $\alpha_{g w}$ (Equation (7)). Hence, a certain deviation of $\alpha_{g w}$ estimated by recession analysis can produce the discrepancies on the estimated value of $B F I_{\max }$. However, according to the performance 
evaluation in different aspects, the results of RDF-E and RDF-M using the value of $B F I_{\max }(0.92)$ were found consistent with the results of the isotope-based method (Section 3.2.4). Therefore, in the study area, it was appropriated to estimate the value of $B F I_{\max }$ by backward filtering operation.

If we compare our study area to the other desert areas, we find that both areas possess sandy soil with a high infiltration rate and flash flood is a significant feature in some of the desert land [53]. However, in our study area, the stream maintained a relatively stable water level due to the contribution of groundwater during the dry period which was rare in desert areas. During the rainy season, the contribution of groundwater to streamflow was still high in our study area which produced high quantity baseflow, while for many desert areas the groundwater contribution was relatively small to generate low baseflow amount [54]. According to Figure 8, the filtering methods could not effectively identify the baseflow during the precipitation event. Therefore, we assume that the filtering methods could apply to the other desert areas, but in our study area, they were not suitable. The recursive digital filtering method with Eckhardt (RDF-E) could be applied in both areas as it produced better results in baseflow separation. In the study area, the quick flow was formed during the heavy rainfall but in the nonprecipitation period, the base flow was approximately equal to streamflow (Figure $8 \mathrm{~h}$ ). In comparison to RDF-E with RDF-M during the nonprecipitation period (e.g., 1 November 2011 to March 2011 in Figure 8), the latter produced baseflow similar to streamflow while the former generated a difference between baseflow and streamflow as the former misidentified some quick flow components (Figure 8f,g). The incorporation of precipitation information in RDF-M made it more robust for the separation of base flow than other methods.

\subsection{The Sensitivity Analysis of RDF-M}

Compared with RDF-E, RDF-M required three additional parameters: quick flow duration $N$, $\mathrm{N}$-day cumulative precipitation $A P$, and threshold for quick flow $\mathrm{TH}_{p}$ to separate baseflow. In the RDF-M, $A P$ was directly calculated by observed precipitation while $N$ and $T H_{p}$ were determined by experiment or observed values. Similar to the Eckhardt [18], we performed a sensitivity analysis using streamflow records of Figure 8 on these two parameters. To this purpose, one parameter was changed in turn, keeping the other one constant. In this case, the sensitivity index I was equal to the relative change of BFI divided by the relative change of parameter (Table 4). It was found that the parameter $T H_{p}$ possessed a weaker influence on the calculated baseflow index than the parameter $N$. The variation of $N$ induced a change in the calculated $N$-day cumulative precipitation $A P$, which in turn caused a certain change in the separated baseflow. This may explain why $N$ was more sensitive than $\mathrm{TH}_{p}$. Both observed flood processes and isotope experiments showed that the duration of the quick flow in the study area was about five days; thus, this value could be considered to rightly reflect the realistic situation of the basin. Then, whether the streamflow fluctuation is caused by quick flow can be confirmed by $A P$ and $T_{p}$ (Figure 2). To make the accumulated precipitation more consistent with the actual situation of the basin, we used the areal precipitation calculated by the Thiessen polygons method to contribute to the calculation.

Table 4. Results of the sensitivity analysis for RDF-M.

\begin{tabular}{cccc}
\hline $\begin{array}{c}\text { Quick Flow Duration } \boldsymbol{N} \\
\text { (Days) }\end{array}$ & $\begin{array}{c}\text { Threshold for Quick } \\
\text { Flow } \mathbf{T H}_{\boldsymbol{p}} \mathbf{( \mathbf { m m } )}\end{array}$ & Baseflow Index & Sensitivity Index I (\%) \\
\hline 5 & 1 & 0.964 & \\
5 & 0.5 & 0.957 & 1.45 \\
5 & 1.5 & 0.968 & 0.83 \\
5 & 2 & 0.969 & 0.52 \\
3 & 1 & 0.974 & -2.59 \\
7 & 1 & 0.96 & -1.04 \\
10 & 1 & 0.951 & -1.35 \\
\hline
\end{tabular}




\subsection{The Annual Variation of Baseflow and Quick Flow of the Hailiutu River Basin}

Yang et al. [33] used several methods to detect the change points of the annual mean streamflow of the Hailiutu River Basin, and results showed that there were four major shifts in mean streamflow $(1968,1986,1992$, and 2001). Studies have shown that some reservoirs were constructed around 1968 in the Hailiutu River basin, and the construction of these reservoirs caused the regime shift of annual mean streamflow [33,34]. During the period 1986-2001, the amount of irrigation water and water diversion were increased with the result that the annual mean streamflow brought regime shifts in 1986 and 2001 [55]. In this study, the proposed method, RDF-M, was applied to historical streamflow data to find variability of the annual mean baseflow and annual mean quick flow of the Hailiutu River basin. Due to the high BFI value (0.954) calculated by RDF-M using the historical streamflow data of this basin, the variation of streamflow and baseflow were nearly similar and the change points of annual mean baseflow were identified as 1968, 1986, and 2001 (Figure 12a) which were similar to that of the annual mean streamflow. For annual mean quick flow, only one change point was detected: 1968 (Figure 12b). This shift occurred due to the construction of the reservoir in the Hailiutu River basin at that period.

\subsection{Limitations and Outlook}

In this study, isotope tracer technology was applied to investigate the contribution of different water sources to streamflow only during one flood period (Section 3.1). During the experiment, the streamflow data logger got damaged, hence we could not collect the streamflow data from the instrument. The contributions of water sources to streamflow investigated by isotopes was sensitive to the intensity of precipitation and the duration of precipitation $[13,56]$. Thus, in the future, the collection of isotope data under more flood events should be considered, and the runoff generation characteristics will be further analyzed in conjunction with the streamflow data. Meanwhile, the artificial neural network technique $[7,57-59]$ can also be applied in our study area to understand the characteristics of runoff but it is out of the scope of this study. In this paper, by introducing precipitation information, we propose an improved RDF-E method called RDF-M to develop the accuracy of baseflow separation. The analysis shown here is valid for a semi-arid sandy area where streamflow is mainly recharged by groundwater and analysis should be extended to other regions.

\section{Conclusions}

In this paper, the tracer-based method was applied to analyze the contributions of surface water, soil water, and groundwater to streamflow during a flood period. The adaptability of several baseflow separation methods was analyzed and compared, and the suitable baseflow method for the Hailiutu River basin was investigated. Considering the deficiency of the recursive digital filter with Eckhardt (RDF-E) method, a new baseflow separation method combining precipitation information with RDF-E called RDF-M was proposed. The main conclusions were as follows:

1. During the experiment from 23 July to 31 July 2016, it was found that groundwater was the main source of streamflow, the quick flow duration was about five days, and the contributions of groundwater, soil water, and surface flow to streamflow were $70 \%, 27 \%$, and $3 \%$ respectively.

2. Using the streamflow data from 1 November 2010 to 31 October 2011 and the results of baseflow by tracer-based method found in previous studies was considered as a standard for the determination of performances of filtering methods and recursive digital filtering methods (Section 3.2.4). With the comparison of the above results, the filtering methods including the Hydrograph Separation Program (HYSEP) and UK Institute of Hydrology's method (UKIH) clearly underestimated the baseflow while both the RDF-E and RDF-M method were found effective for separation of baseflow. During the nonprecipitation period, the RDF-M method produced baseflow similar to the streamflow which accorded with the actual situation of the Hailiutu River basin while the 
RDF-E method generated some variations between baseflow and streamflow as it misidentified quick flow values.

3. By analyzing the historical streamflow (1957-2014) of the Hailiutu River basin, the baseflow/quick flow was separated using the RDF-M method. The three change points $(1968,1986$, and 2001) of separated baseflow were detected by the sequential $t$-test analysis of the regime shift (STARS) process while only one change point (1968) was found for mean quick flow.

Author Contributions: G.S., D.Z. and Y.G. were primarily accountable for data collection and design and coordination of the study; G.S. and M.A.S. were responsible for writing of the paper; G.S. and F.H. were responsible for data analysis and results presentation. All authors have read and agreed to the published version of the manuscript.

Funding: This research was supported by the National Key R\&D Program of China(2017YFC0406101); the National Natural Science Foundation of China (NSFC51579067), the Qing Lan Project.

Conflicts of Interest: The authors declare no conflict of interest.

\section{References}

1. Stewart, M.K. Promising new baseflow separation and recession analysis methods applied to streamflow at Glendhu Catchment, New Zealand. Hydrol. Earth Syst. Sci. 2015, 19, 2587-2603. [CrossRef]

2. Koskelo, A.I.; Fisher, T.R.; Utz, R.M.; Jordan, T.E. A new precipitation-based method of baseflow separation and event identification for small watersheds $\left(<50 \mathrm{~km}^{2}\right)$. J. Hydrol. 2012, 450-451, 267-278.

3. Yin, L.; Hou, G.; Huang, J.; Li, Y.; Wang, X.; Yang, Z.; Zhou, Y. Using chloride mass-balance and stream hydrographs to estimate groundwater recharge in the Hailiutu River Basin, NW China. In Proceedings of the 2011 International Symposium on Water Resource and Environmental Protection, Xi'an, China, 20-22 May 2011; Volume 1, pp. 325-328.

4. Ahiablame, L.; Chaubey, I.; Engel, B.; Cherkauer, K.; Merwade, V. Estimation of annual baseflow at ungauged sites in Indiana USA. J. Hydrol. 2013, 476, 13-27. [CrossRef]

5. Gao, Z.; Zhang, L.; Cheng, L.; Zhang, X.; Cowan, T.; Cai, W.; Brutsaert, W. Groundwater storage trends in the Loess Plateau of China estimated from streamflow records. J. Hydrol. 2015, 530, 281-290. [CrossRef]

6. Nalley, D.; Adamowski, J.; Khalil, B. Using discrete wavelet transforms to analyze trends in streamflow and precipitation in Quebec and Ontario (1954-2008). J. Hydrol. 2012, 475, 204-228. [CrossRef]

7. Taormina, R.; Chau, K.W.; Sivakumar, B. Neural network river forecasting through baseflow separation and binary-coded swarm optimization. J. Hydrol. 2015, 529, 1788-1797. [CrossRef]

8. Mei, Y.; Anagnostou, E.N. A hydrograph separation method based on information from rainfall and runoff records. J. Hydrol. 2015, 523, 636-649. [CrossRef]

9. Szilagyi, J.; Parlange, M.B. Baseflow separation based on analytical solutions of the Boussinesq equation. J. Hydrol. 1998, 204, 251-260. [CrossRef]

10. Lin, K.; Guo, S.; Zhang, W.; Liu, P. A new baseflow separation method based on analytical solutions of the Horton infiltration capacity curve. Hydrol. Process. 2007, 21, 1719-1736. [CrossRef]

11. Arnold, J.G.; Muttiah, R.S.; Srinivasan, R.; Allen, P.M. Regional estimation of base flow and groundwater recharge in the Upper Mississippi river basin. J. Hydrol. 2000, 227, 21-40. [CrossRef]

12. Luo, Y.; Arnold, J.; Allen, P.; Chen, X. Baseflow simulation using SWAT model in an inland river basin in Tianshan Mountains, Northwest China. Hydrol. Earth Syst. Sci. 2012, 16, 1259-1267. [CrossRef]

13. Klaus, J.; McDonnell, J.J. Hydrograph separation using stable isotopes: Review and evaluation. J. Hydrol. 2013, 505, 47-64. [CrossRef]

14. Lott, D.A.; Stewart, M.T. Base flow separation: A comparison of analytical and mass balance methods. J. Hydrol. 2016, 535, 525-533. [CrossRef]

15. Zhang, R.; Li, Q.; Chow, T.L.; Li, S.; Danielescu, S. Baseflow separation in a small watershed in New Brunswick, Canada, using a recursive digital filter calibrated with the conductivity mass balance method. Hydrol. Process. 2013, 27, 2659-2665. [CrossRef]

16. Stewart, M.; Cimino, J.; Ross, M. Calibration of base flow separation methods with streamflow conductivity. Ground Water 2007, 45, 17-27. [CrossRef] 
17. Gustard, A.; Marshall, D.C.W.; Sutcliffe, M.F. Low Flow Estimation in Scotland; Institute of Hydrology: Wallingford, UK, 1987.

18. Eckhardt, K. How to construct recursive digital filters for baseflow separation. Hydrol. Process. 2005, 19, 507-515. [CrossRef]

19. Gonzales, A.L.; Nonner, J.; Heijkers, J.; Uhlenbrook, S. Comparison of different base flow separation methods in a lowland catchment. Hydrol. Earth Syst. Sci. 2009, 13, 2055-2068. [CrossRef]

20. Rutledge, A.T. Computer Programs for Describing the Recession of Ground-Water Discharge and for Estimating Mean Ground-Water Recharge and Discharge from Streamflow Records-Update. In Water-Resources Investigations Report; US Geological Survey: Reston, VA, USA, 1998.

21. Lyne, V.; Hollick, M. Stochastic time-variable rainfall-runoff modelling. In Proceedings of the Institute of Engineers Australia National Conference, Perth, Australia, 10-12 September 1979.

22. Chapman, T. A comparison of algorithms for stream flow recession and baseflow separation. Hydrol. Process. 1999, 13, 701-714. [CrossRef]

23. Gan, R.; Zuo, Q. Assessing the digital filter method for base flow estimation in glacier melt dominated basins. Hydrol. Process. 2016, 30,1367-1375. [CrossRef]

24. Wang, D. On the base flow recession at the Panola Mountain Research Watershed, Georgia, United States. Water Resour. Res. 2011, 47. [CrossRef]

25. Eris, E.; Wittenberg, H. Estimation of baseflow and water transfer in karst catchments in Mediterranean Turkey by nonlinear recession analysis. J. Hydrol. 2015, 530, 500-507. [CrossRef]

26. Wu, J.; Miao, C.; Duan, Q.; Lei, X. Dynamics and Attributions of Baseflow in the Semiarid Loess Plateau. J. Geophys. Res. Atmos. 2019, 124, 3684-3701. [CrossRef]

27. Hou, L.; Wenninger, J.; Shen, J.; Zhou, Y.; Bao, H.; Liu, H. Assessing crop coefficients for Zea mays in the semi-arid Hailiutu River catchment, northwest China. Agric. Water Manag. 2014, 140, 37-47. [CrossRef]

28. Jin, X.M.; Guo, R.H.; Zhang, Q.; Zhou, Y.X.; Zhang, D.R.; Yang, Z. Response of vegetation pattern to different landform and water-table depth in Hailiutu River basin, Northwestern China. Environ. Earth Sci. 2013, 71, 4889-4898. [CrossRef]

29. Lv, J.; Wang, X.-S.; Zhou, Y.; Qian, K.; Wan, L.; Eamus, D.; Tao, Z. Groundwater-dependent distribution of vegetation in Hailiutu River catchment, a semi-arid region in China. Ecohydrology 2013, 6, 142-149. [CrossRef]

30. Yang, Z.; Zhou, Y.; Wenninger, J.; Uhlenbrook, S. A multi-method approach to quantify groundwater/surface water-interactions in the semi-arid Hailiutu River basin, northwest China. Hydrogeol. J. 2014, 22, 527-541. [CrossRef]

31. Shao, G.; Guan, Y.; Zhang, D.; Yu, B.; Zhu, J. The Impacts of Climate Variability and Land Use Change on Streamflow in the Hailiutu River Basin. Water 2018, 10, 814. [CrossRef]

32. Wu, J.; Qian, H.; Li, P.; Song, Y. A system-theory-based model for monthly river runoff forecasting: Model calibration and optimization. J. Hydrol. Hydromech. 2014, 62, 82-88. [CrossRef]

33. Yang, Z.; Zhou, Y.; Wenninger, J.; Uhlenbrook, S. The causes of flow regime shifts in the semi-arid Hailiutu River, Northwest China. Hydrol. Earth Syst. Sci. 2012, 12, 87-103. [CrossRef]

34. Zhou, Y.; Yang, Z.; Zhang, D.; Jin, X.; Zhang, J. Inter-catchment comparison of flow regime between the Hailiutu and Huangfuchuan rivers in the semi-arid Erdos Plateau, Northwest China. Hydrol. Sci. J. 2015, 60, 688-705. [CrossRef]

35. Yang, Z.; Zhou, Y.; Wenninger, J.; Uhlenbrook, S.; Wan, L. Simulation of groundwater-surface water interactions under different land use scenarios in the Bulang catchment, Northwest China. Water 2015, 7, 5959-5985. [CrossRef]

36. Zhou, Y.; Wenninger, J.; Yang, Z.; Yin, L.; Huang, J.; Hou, L.; Wang, X.; Zhang, D.; Uhlenbrook, S. Groundwater-surface water interactions, vegetation dependencies and implications for water resources management in the semi-arid Hailiutu River catchment, China-A synthesis. Hydrol. Earth Syst. Sci. 2013, 17, 2435-2447. [CrossRef]

37. Visconti, F.; de Paz, J.M.; Martínez, D.; Molina, M.J. Laboratory and field assessment of the capacitance sensors Decagon 10HS and 5TE for estimating the water content of irrigated soils. Agric. Water Manag. 2014, 132, 111-119. [CrossRef]

38. Phillips, D.L.; Newsome, S.D.; Gregg, J.W. Combining sources in stable isotope mixing models: Alternative methods. Oecologia 2005, 144, 520-527. [CrossRef] [PubMed] 
39. Piggott, A.R.; Moin, S.; Southam, C. A revised approach to the UKIH method for the calculation of baseflow/Une approche améliorée de la méthode de l'UKIH pour le calcul de l'écoulement de base. Hydrol. Sci. J. 2005, 50, 920. [CrossRef]

40. Aksoy, H.; Unal, N.E.; Pektas, A.O. Smoothed minima baseflow separation tool for perennial and intermittent streams. Hydrol. Process. Int. J. 2008, 22, 4467-4476. [CrossRef]

41. Pettyjohn, W.A.; Henning, R. Preliminary Estimate of Ground-Water Recharge Rates, Related Streamflow and Water Quality in Ohio; Ohio State University: Columbus, OH, USA, 1979.

42. White, K.E.; Sloto, R.A. Baseflow frequency characteristics of selected Pennsylvania streams. In Water-Resources Investigations Report; US Geological Survey: Reston, VA, USA, 1990.

43. Eckhardt, K. A comparison of baseflow indices, which were calculated with seven different baseflow separation methods. J. Hydrol. 2008, 352, 168-173. [CrossRef]

44. Collischonn, W.; Fan, F.M. Defining parameters for Eckhardt's digital baseflow filter. Hydrol. Process. 2013, 27, 2614-2622. [CrossRef]

45. Yang, Z.-Y.; Wang, K.; Yuan, Y.; Huang, J.; Chen, Z.-J.; Li, C. Non-Negligible Lag of Groundwater Infiltration Recharge: A Case in Mu Us Sandy Land, China. Water 2019, 11, 561. [CrossRef]

46. Moriasi, D.N.; Arnold, J.G.; Van Liew, M.W.; Bingner, R.L.; Harmel, R.D.; Veith, T.L. Model Evaluation Guidelines for Systematic Quantification of Accuracy in Watershed Simulations. Trans. ASABE 2007, 50, 885-900. [CrossRef]

47. Pingale, S.M.; Khare, D.; Jat, M.K.; Adamowski, J. Spatial and temporal trends of mean and extreme rainfall and temperature for the 33 urban centers of the arid and semi-arid state of Rajasthan, India. Atmos. Res. 2014, 138, 73-90. [CrossRef]

48. Rodionov, S.N. A sequential algorithm for testing climate regime shifts. Geophys. Res. Lett. $2004,31$. [CrossRef]

49. Lange, J.; Leibundgut, C. Surface runoff and sediment dynamics in arid and semi-arid regions. In Understanding Water in a Dry Environment; CRC Press: London, UK, 2005; pp. 131-166.

50. Tao, L.; Honglang, X.; Xinrong, L. Modeling the effects of crust on rain infiltration in vegetated sand dunes in arid desert. Arid Land Res. Manag. 2001, 15, 41-48. [CrossRef]

51. Yair, A. Runoff generation in a sandy area-The Nizzana sands, Western Negev, Israel. Earth Surf. Process. Landf. 1990, 15, 597-609. [CrossRef]

52. Li, L.; Maier, H.R.; Partington, D.; Lambert, M.F.; Simmons, C.T. Performance assessment and improvement of recursive digital baseflow filters for catchments with different physical characteristics and hydrological inputs. Environ. Model. Softw. 2014, 54, 39-52. [CrossRef]

53. Fisher, S.G.; Grimm, N.B. Hydrologic and material budgets for a small Sonoran Desert watershed during three consecutive cloudburst floods. J. Arid Environ. 1985, 9, 105-118. [CrossRef]

54. Beck, H.E.; van Dijk, A.I.J.M.; Miralles, D.G.; de Jeu, R.A.M.; Bruijnzeel, L.A.; McVicar, T.R.; Schellekens, J. Global patterns in base flow index and recession based on streamflow observations from 3394 catchments. Water Resour. Res. 2013, 49, 7843-7863. [CrossRef]

55. Yang, Z.; Zhou, Y.; Wenninger, J.; Uhlenbrook, S.; Wang, X.; Wan, L. Groundwater and surface-water interactions and impacts of human activities in the Hailiutu catchment, northwest China. Hydrogeol. J. 2017, 25, 1341-1355. [CrossRef]

56. Gou, J.; Qu, S.; Shi, P.; Li, D.; Chen, X.; Wang, Y.; Shan, S.; Si, W. Application of Stable Isotope Tracer to Study Runoff Generation during Different Types of Rainfall Events. Water 2018, 10, 538. [CrossRef]

57. Moazenzadeh, R.; Mohammadi, B.; Shamshirband, S.; Chau, K. Coupling a firefly algorithm with support vector regression to predict evaporation in northern Iran. Eng. Appl. Comput. Fluid Mech. 2018, 12, 584-597. [CrossRef]

58. Ahmad, S.; Simonovic, S.P. An artificial neural network model for generating hydrograph from hydro-meteorological parameters. J. Hydrol. 2005, 315, 236-251. [CrossRef]

59. Taormina, R.; Chau, K.-W.; Sethi, R. Artificial neural network simulation of hourly groundwater levels in a coastal aquifer system of the Venice lagoon. Eng. Appl. Artif. Intell. 2012, 25, 1670-1676. [CrossRef]

(C) 2020 by the authors. Licensee MDPI, Basel, Switzerland. This article is an open access article distributed under the terms and conditions of the Creative Commons Attribution (CC BY) license (http://creativecommons.org/licenses/by/4.0/). 